\title{
Absorptive Capacity and Knowledge Flows for Large International Firms: A Survey*
}

\author{
Luigi Aldieri \\ University of Naples Parthenope, Naples, Italy
}

\begin{abstract}
The main objective of this paper is that of surveying both theoretic and econometric models exploring the existence of knowledge spillovers and quantifying firm's ability to identify, assimilate, and exploit existing information (absorptive capacity). In so doing, we explore different methodologies through which we may analyze the knowledge transmission: both the production function approach and the knowledge function approach. In order to construct the spillover stocks, different dimensions are considered: geographic and technological.
\end{abstract}

Keywords: R\&D investments, technological innovation, knowledge diffusion, absorptive capacity, knowledge spillovers

\section{Introduction}

The diffusion of knowledge regards international technical communication, multinational corporations, international trade and direct capital investments among different technological areas.

Cohen and Levinthal (1989) argue that research and development (R\&D) investments have two targets: They generate new information (innovation process), and they enhance the firm's ability to identify, assimilate and exploit existing information (learning process or absorptive capacity).

A fundamental difference between the learning-by-doing process and the absorptive capacity is that in the former case, the production of the output becomes more efficient, through the repetition of the industrial process, while in the latter one, agents receive new ideas from outside to realize a new product.

Technological knowledge is a public good, suggesting the existence of the indirect effects of own R\&D capital on other firms productivity; these effects are generally called spillovers (Griliches, 1992).

Knowledge external to a production unit is a combination of R\&D performed by other production units (firms, regions or countries) somehow weighted to account for the intensity of knowledge flows between the source and the destination.

Regardless of the way external knowledge has been measured, its impact has been assessed mainly within two different frameworks: by introducing the chosen measure into an aggregate production function or into a knowledge production function. In the first case, the aim is to assess the impact of spillovers on productivity, while in the second case their effect is measured directly on innovation.

The paper is organised as follows. Section 2 reviews the main approaches proposed in the literature to

\footnotetext{
* Acknowledgement: The author kindly thanks two anonymous referees for the very useful comments to the previous version of this paper. The usual disclaimer applies.

Luigi Aldieri, assistant professor, Department of Economic Studies “Salvatore Vinci”, University of Naples Parthenope.
} 
formalize the impact of R\&D spillovers on firms' economic performance, while their empirical findings are summarised in the section 3. Finally, conclusions discuss some points deserving further research.

\section{Framework to Formalize the R\&D Spillovers: A Review of the Literature}

\section{Technological Proximity}

Knowledge externalities are realized into two steps. Knowledge flows represent the first step and take place whenever ideas generated by a firm or country are learned by another firm or country. Such learning creates a pool of accessible external knowledge, which has a positive effect on productivity, however measured (this is the second step).

Griliches (1979) identifies two sources of potential externalities generated by R\&D activities: rent spillovers and pure knowledge spillovers. Rent spillovers arise when the prices of intermediate inputs purchased from other firms or countries are not fully adjusted for quality improvements resulting from R\&D investment. As such, they originate from economic transactions and are the consequence of "measurement errors".

By contrast, pure knowledge spillovers arise because of the imperfect appropriability of ideas: The benefits of new knowledge accrue not only to the innovator, but "spill over" to other firms or countries, thus enriching the pool of ideas upon which subsequent innovations can be based. Hence knowledge spillovers may occur without any economic transactions and are not the manifestation of any measurement error.

Theoretically, the distinction between the two concepts of spillovers seems clear, but their empirical identification is rather more complex. One reason for this ambiguity is that economic transactions that originate rent spillovers may also imply some knowledge transfers ${ }^{1}$.

Further difficulties arise because innovation by competitors may also generate strategic effects. If technological rivalry is strong and means of appropriation are effective, firms could find themselves engaged into a race for the appropriation of new profitable ideas. As a consequence, the positive technological externality arising from other firms' research can potentially be confounded with a negative effect due to the competition.

A key issue in the empirical analysis on knowledge spillovers is the measurement of the pool of external knowledge. This is usually built as the amount of R\&D conducted elsewhere weighted by some measure proximity in the technological or geographic space, taken to be representative of intensity of knowledge flows between the source and the recipient of spillovers.

Different proximity measures have been used in the literature. The first one was employed by Bernstein and Nadiri (1989), who built the pool of knowledge external to a firm as the unweighted sum of the R\&D spending by other firms in the same industry. The total unweighted stock of R\&D spillovers $\left(T U_{i}\right)$ is computed as follows:

$$
T U_{i}=R_{-} i-R_{i}
$$

where $R_{-} i$ is the total amount of R\&D performed in $i$ industry, and $R_{i}$ is firm's $i$ own R\&D expenditure.

This measure is fairly unsatisfactory as it assumes that a firm equally benefits from R\&D of all other firms in the same industry and does not benefit at all from R\&D conducted by firms in other industries. Results on spillovers based on industry measures like this might also capture spurious effects due to common industry

\footnotetext{
${ }^{1}$ As pointed out in Cincera and Van Pottelsberghe de la Potterie (2001), there are also other channels through which rent spillovers potentially operate: transaction in investment goods and the use by one firm or country of patents granted to other firms or countries.
} 
trends and shocks.

Many authors agree that the measure of technological spillovers should be a weighted sum of R\&D capital stock of other firms. However, there is not a consensus on the weighting system to be used. The most commonly used methods are based on either patent data (Jaffe, 1986; Jaffe, 1988; Los \& Verspagen, 2000; Cincera, 2005; Aldieri \& Cincera, 2009) or input-output matrices (Wakelin, 2001; Medda \& Piga, 2004; Aiello \& Pupo, 2004; Aiello \& Cardamone, 2005).

A complex and commonly used measure of technological proximity was the one introduced by Jaffe (1986). According to this procedure, each firm is associated to a vector describing the distribution of its patents across technology classes. Such vector represents the firm's location in multi-dimensional technology space. Proximity between two firms is then obtained as the uncentered correlation coefficient between the corresponding location vectors.

According to this procedure, the total weighted stock of R\&D spillovers has performed as follows:

$$
T S_{i}=\sum_{i \neq j} P_{i j} K_{j}
$$

where $P_{i j}$ is the technological proximity between firm $i$ and $j, K_{j}$ is firm's $j$ R\&D capital.

In particular:

$$
P_{i j}=\frac{\sum_{k=1}^{K} T_{i k} T_{j k}}{\sqrt{\sum_{k=1}^{K} T_{i k}^{2} \sum_{k=1}^{K} T_{j k}^{2}}}
$$

where $T$ is the vector of technological position, regarding $K$ industries.

From an empirical perspective, the questions to deal with before measuring the proximity between the firms are relative to the choice of the variables which define the technological space. Several authors (Jaffe, 1986; Los \& Verspagen, 2000; Cincera, 2005; Aldieri \& Cincera, 2009) argue that patent data allow the definition of an innovative space, others use investments in R\&D (Harhoff, Narin, Schrer, \& Vopel, 1999; Adams \& Jaffe, 1996), Inkmann and Pohlmeier (1995) consider a set of firm characteristics, such as size, demand expectations, industry affiliation, while Aiello and Cardamone (2008) take into account investments in ICT, the internal and external R\&D investments, the ratio between the number of skilled workers and the number of unskilled workers and the Herfindahl-Hirschman index, as a measure of market concentration in the sector which the firm belongs to.

The index of technological distance relies on the strong assumption that the appropriability conditions of knowledge are the same for all firms (Jaffe, 1988). The more the outcomes of R\&D activities are appropriable, the less there will be flows of knowledge between R\&D performers and the potential users of this knowledge. In estimating the spillover effects, one should use industrial or technologically narrowly defined sector dummies. Since these variables are not observable at the firm level, their direct assessment is hard to pick up. In panel data context, in order to attenuate this matter, one may assume that these firms' specific unobserved effects are constant over the period considered.

The question of whether firm's position into the technological space is fixed or not is another issue which is empirically difficult to verify. Indeed, firms’ R\&D activities evolve over time, so does their technological position. However, there is reason to claim that over a short time period, the firms' position in the technological 
space is to be fixed.

Another drawback of this procedure is that the uncentered correlation index for measuring technological proximities is a symmetric index. The technological proximity of firm A and firm B is the same as the one between the firm B and firm $\mathrm{A}$.

It would be interesting to use an asymmetrical index so one could separate the ability of firm A in capturing benefits from firm B' R\&D from the one of firm B. Indeed, large and diversified firms have relative advantages in appropriating results from outside R\&D.

In order to attempt to overcome the unrealistic assumption of symmetry, Aiello and Cardamone (2008) assumed that the firm's absorptive capacity is strongly dependent on the quality of its human capital (Lucas, 1988; Vinding, 2006; Wang, 2007). For this reason, they multiply equation (3) by the following expression:

$$
\left[\frac{h_{i t}}{\max \left(h_{i t}, h_{j t}\right)}\right]
$$

where the variable $h$ is a measure of human capital (such as the years of schooling).

One alternative to Jaffe's procedure is to use Euclidean distance between technological vectors endpoints ${ }^{2}$. But this measure depends on the technological vector's length. The more the firms are diversified, the lesser the length of their technological vectors will be. They will be close each other even if their technological vectors are orthogonal, because they will be located in a central region of the technological space. The uncentered correlation coefficient is independent of technological vectors' length. A second possibility is to depart from the uncentered correlation proximity measure and apply some transformations to it. Suppose that the technological distance is $P_{i j}=0.5$. We could investigate whether firms benefit more or much less from R\&D spillovers than firms at the extreme, i.e., firms very close or very distant from other firms by assuming that the technological distance of firms is a multiplicative function of the $P_{i j}$ Another possible transformation is to look at the logarithmic reciprocal function. Formally, the transformed $P_{i j}$ lead to the following formulation:

$$
P_{i j}^{*}=P_{i j}^{\varphi}
$$

for the multiplicative function, and:

$$
P_{i j} * *=\exp \left(\phi *\left(1-\frac{1}{P_{i j}}\right)\right)
$$

for the reciprocal logarithmic one.

The shapes characterizing these transformed proximity measures depend on the parameters $\phi$ and $\varphi$ of the reciprocal logarithmic and multiplicative functions. The different proximity measures can be tested by letting the parameter of each function vary over a range of values and see what happens, from a statistical point of view, i.e., in terms of the regression's overall fit and estimated standard errors associated with the estimated spillover variables.

\section{Geographic Proximity}

It is worth noting the geographic dimensions of knowledge spillovers. The innovation production function was aspatial or insensitive to issues involving location and geography. Empirical results hinted that knowledge production had a spatial dimension. Armed with a new theoretical understanding about the role and significance of knowledge spillovers, and the manner in which they are localized, some economists began to estimate the

\footnotetext{
${ }^{2}$ See Cincera (2005) for an empirical application of the Euclidean distance to technological proximity.
} 
knowledge production function with a spatial dimension. Location and geographic space have become key factors in explaining the determinants of innovation and technological change.

It is commonly agreed that the flows of innovation depend not only on the technological, but also on the geographical distance between firms: face-to-face contacts enhance knowledge spillovers whatever the technological proximity. Much important knowledge is tacit and dependent on the particular circumstances of time and place, and therefore cannot be acquired by traditional market research procedures or transmitted by long-distance learning. Even though experienced people can be relocated and modern transportation makes it easier than ever to carry people from one location to another, there is no better way to have frequent interaction between individuals than by close geographical proximity (Gertler, 1995; Von Hippel, 1994), according to Macdonald (1992): Individuals work for firms and much of their value to their employers is related to network membership.

Geographical proximity often greatly facilitates the building of bonds of trust between people, because of the frequent interactions and long-term contracts or commitments between people that it allows in both working environments and social activities.

Interaction with customers and suppliers, along with information about new technologies and ways to deal with non routine situations, is critical to business success. Even though many people maintain that such knowledge can be conveyed over screens and telephone calls, the fact remains that much useful economic information and technical know-how still remain in a tacit, rather than explicit, form. As such, most valuable knowledge is embodied in people and is not amenable to any formalized mode of communication. One of the ways that firms' owners and employees can tap into the tacit knowledge of other people is by being located in close geographical proximity to them. As we argued, such industrial concentration favors the mobility of skilled workers from one firm to another, makes interactions between producers and users much easier, enforces reputation effects, lessens the risks of opportunistic behaviour and therefore facilitates exchange of information between competitors. The localization of a firm within a relevant industrial district can enhance the capability of its employees to generate, diffuse and absorb tacit knowledge, thereby facilitating day-to-day problem solving.

If geographic concentration is not a sufficient condition for innovation, it nonetheless remains a great facilitator in the transmission of tacit knowledge.

Also to identify a geographic proximity measure there exist different techniques.

According to one methodology, each firm of the sample is to be located into a multi-dimensional space. To this end, each firm is assumed to exist at the geographic centroid of the county location of its corporate headquarters. A circle is effectively drawn around each firm, and all other firms that fall inside the circle are defined geographically near. The remaining firms are defined as geographically distant.

Specifically, each firm's geographic location is defined with the state and county name. Each observation in the dataset reports the latitude and the longitude of the geographic centroid of a county in degrees, minutes, and seconds. The distance between any two firms in a given year is then computed as the distance between their respective county centroids. Assuming a spherical earth of actual earth volume, the arc distance in miles between any two firms $i$ and $j$ can be derived according to the Haversine formula:

$$
d_{i j}=2 * 3.959 * \arcsin \sqrt{\sin ^{2}\left(\frac{\text { lat }_{j}-\text { lat }_{i}}{2}\right)+\cos \left(\text { lat }_{j}\right)+\cos \left(\text { lat }_{i}\right) \sin ^{2}\left(\frac{\cos \left(\operatorname{lon}_{j}\right)-\cos \left(\operatorname{lon}_{i}\right)}{2}\right)}
$$

where 3.959 is the radius of the earth in miles; latitude and longitude values are in radians. 
Use of corporate headquarters to represent firm location may be questionable for the purpose of spillover detection. One may argue that our true interest is in the location of innovation, not necessarily in the location of corporate headquarters. However, if firms view R\&D as their most strategically important investment they are likely to locate this activity close to corporate headquarters.

Furthermore, while R\&D may be a reasonable proxy of the scale of a firm's innovative activity, spillovers from this implied knowledge base may emerge from any of the locations that compose the firm: R\&D facilities, production facilities, or corporate headquarters. Thus, corporate headquarters may be as a good proxy of firm location.

The Directory of American Research and Technology 1993 was consulted to establish the reasonableness of the claim that corporate headquarters may be useful proxy for the source location of R\&D spillovers.

Another way to take into account the geographic space is to consider the following model:

$$
\Delta A_{i}=(R \& D)_{i}^{a} A_{i}^{b} \prod_{i \neq j} A_{j}^{c\left(\text { dist }_{i j}\right)}
$$

where $\Delta A_{i}$ represents the change over the considered period of the stock of knowledge originated in region $i$. Expression (8) says that innovation in region $i$ depends on the Cobb-Douglas combination R\&D resources used in region $i$, and on ideas available to the region at the beginning of the period.

The elasticity of innovation to $\mathrm{R} \& \mathrm{D}$ resources is measured by $a$. Ideas generated in region $i$, enter with elasticity $b$, while ideas generated in other regions enter with elasticity $c$ that depends on the distance in kilometres between region $i$ and region $j$. In particular, one may assume that embodied knowledge does not diffuse passed a maximum distance $K$, and that its impact depends on the distance between regions as a step function. Hence the function $c($ dist $)$ is equal to $c_{k} / n_{i k}$ for dist $_{i j} \in K$, with $K=\left\{\left(\right.\right.$ dist $_{0}$, dist $\left._{1}\right),\left(\right.$ dist $_{1}$, dist $\left.\left._{2}\right), \ldots,(K, \infty)\right\}$. The index $K$ captures a sequence of distance intervals within which the step function is constant and $n_{i k}$ is the total number of regions in the distance-interval $k$ from region $i$. The assumption of no diffusion beyond distance $K$ implies $c(k, \infty)=0$. The specified diffusion process implies that innovation in region $i$ depends on the average stock of ideas generated in regions within the distance-interval $K$ with different sensitivities $c$ for different distance-intervals.

Finally, it is possible to use the great circle formula, which yields the shortest distance between two points on a sphere (Aiello \& Cardamone, 2008). Within each pair of firms $i$ and $j$, the distance between them $\left(d_{i j}\right)$ is computed by considering the distance between the administrative capital of the provinces where the firms operate. Given the distance $\left(d_{i j}\right)$ between a pair of firms, an index of the geographical proximity is:

$$
g_{i t}=1-\frac{d_{i j}}{\max \left(d_{i j}\right)}
$$

where is equal to one when $d_{i j}=0$, that is when the firms $i$ and $j$ are in the same province, and it is zero when $d_{i j}=\max \left(d_{i j}\right)$, that is the distance between $i$ and $j$ equals the maximum distance in a given sample.

Although the proximities based on the technological or geographic space are less likely to be contaminated by pecuniary externalities and common industry effects, evidence of its positive impact on productivity may still be unrelated to knowledge spillovers, but rather the result of spatially correlated technological opportunities. According to Griliches (1992), if new opportunities exogenously arise in a technological area, firms active in that area will increase their R\&D spending and improve their productivity. This would erroneously show up a spillover effect. 


\section{Production Function Approach}

Various approaches have been adopted in the attempt to estimate the effect of spillovers. The most widely used has been to introduce a measure of potential pool of external knowledge into a standard production function framework (Griliches, 1979), either at the firm or at the more aggregate (industry, region, country) level, with the ultimate aim to assess the impact of accessible external R\&D on total factor productivity (TFP).

Formally we get:

$$
\ln Y_{i t}=\alpha_{i}+\lambda_{t}+\beta_{1} \ln C_{i t}+\beta_{2} \ln k_{i t}+\beta_{3} \ln L_{i t}+\gamma \ln X_{i t}+\varepsilon_{i t}
$$

where:

In is the natural logarithm;

$L_{i t}$ is the employment of firm $i$ at time $t$;

$K_{i t}$ is the stock of R\&D capital;

$Y_{i t}$ is the value-added of firm $i$ at time $t$;

$C_{i t}$ is the stock of physical capital;

$\alpha_{i}$ is the firm's specific effect;

$\lambda_{t}$ is a set of time dummies;

$X_{i t}$ is a vector of spillover components;

$\gamma$ is its associated vector of parameters;

$\varepsilon_{i t}$ is the disturbance term.

Estimation error imposed by the use of sales, instead of value-added if not available, as a proxy for output will be confined to the constant term if the charges are some fixed proportion of sales. This assumption will be valid in a panel data setting where a firm fixed-effects model is used. To the extent that variation in materials and energy fraction of sales is an industry or region fixed effect, this assumption should be reasonable in the cross-section through use of industry-and state-specific dummies.

In order to construct the stock of $R \& D$ capital it is possible to use the perpetual inventory method (Griliches, 1979). This method assumes that the current state of knowledge is a result of present and the past R\&D expenditures:

$$
K_{i t}=(1-\partial) K_{i t-1}+R_{i t}=R_{i t}+(1-\partial) R_{i t-1}+(1-\partial)^{2} R_{i t-2} \ldots=\sum_{\tau=0}^{\infty}(1-\partial)^{\tau} R_{i t-\tau}
$$

where $K_{i t}$ is the knowledge capital or the own $\mathrm{R} \& \mathrm{D}$ stock of firm $i$ at time $t . R_{i t}$ is the R\&D expenditures and $1-\partial$ is the rate of depreciation of the knowledge capital.

Regarding the value of the depreciation rate, most studies assume a depreciation rate of $15 \%$. By assuming a log-log functional form of Cobb-Douglas production function, Griliches and Mairesse $(1983,1984)$ and Hall and Mairesse (1995) have experimented with different values of $\partial$ and they have found small changes if not at all in the estimated effects of R\&D capital.

The initial knowledge capital is constructed as in equation (11), and by assuming a growth rate of R\&D equal to $g$ :

$$
k_{i 0}=R_{i 0} \sum_{\tau=0}^{\infty} \frac{(1-\partial)^{\tau}}{(1-g)}=\frac{R_{i 0}}{(g+\partial)}
$$

Here also, a growth rate of $5 \%$ is usually assumed. Regarding the timing of R\&D effects, it is to be expected that R\&D activities do not have an immediate impact on firms' economic performances. Evenson (1968) examines aggregate data for U.S. agriculture and concludes that the lag structure of R\&D takes an 
inverted V shape. He concludes that the peak weight from R\&D flows is at five to eight year lags and little contribution is received from R\&D expenditure at lags in excess of 10 to 16 years. But Wagner (1968) provides survey evidence that these lags are much shorter for industrial R\&D, perhaps reflecting the more applied nature of private R\&D expenditures.

Terleckij (1974) suggested also an alternative method to construct the R\&D stock of knowledge. This approach estimates the rate of returns to R\&D instead of its elasticities. To this end, the firm's own R\&D capital is replaced by the firm's R\&D intensity measured as the ratio between the level of R\&D expenditures and the firm's output, i.e., net sales or added value.

Since Cobb-Douglas specification is somewhat restrictive in that it requires the elasticity of substitution between factors to be unity, Aiello and Cardamone (2008) adopted a translog production function. This is a generalization of the Cobb-Douglas and allows to determine to what extent external technology is complementary to or a substitute for private inputs (i.e., labour, physical, human and technological capital). Indeed, we may consider the elasticity of substitution proposed by Morishima (1967), which is a measurement of how the $s, k$ input ratio responds to a change in the $k$ th price. Thus, two inputs are substitute (complements) when the Morishima elasticity (which is not symmetric) is positive (negative).

Aiello and Cardamone (2008), for example, find that labour and physical capital, and labour and R\&D spillovers are Morishima substitutes, while R\&D capital and R\&D spillovers are Morishima complements.

\section{Knowledge Approach}

Difficulties in measuring prices precisely and adjusting them for quality improvements make the production function approach not particularly suited to distinguish technological externalities from pecuniary externalities.

For this reason, some authors have implemented the "knowledge production function" methodological framework introduced by Pakes and Griliches (1984). Within this framework research, efforts and knowledge spillovers are mapped into knowledge increments, most often proxied by patents. Since the production of innovation (patents) does not require intermediates inputs and is not evaluated using prices, but simply the quantity of innovations, it minimises the role of rent externalities.

Patents are count data and occur in integers. These characteristics are known to generate bias in estimates of the log-linear models and motivate the estimation of alternative non-linear models.

Regardless of the model chosen (linear versus non-linear), a concern in the estimation of equations resides in the complex structure of the individual effect, which is characterized by correlation across panels, hence by a residual variance-covariance matrix that is not longer block diagonal. If such correlation is ignored, inferences based on OLS or random effect estimation might then be mislead since estimated standard errors are biased downward. By contrast, fixed effect estimates are conditional on the individual effects which leaves the standard errors unaffected. Furthermore, fixed effects methods ensure consistency in the presence of correlation between the explanatory variables and the individual effects. For the above reason, fixed effect methods, although inefficient, are to be preferred.

The basic model found in the literature to handle count data is the Poisson model, which has been extensively used to model patents as a function of R\&D (Hall, Hausman, \& Griliches, 1984).

This model estimates the relationship between the arrival rate of patents and the independent variables. The dependent variable $y_{i t}$ is assumed to have a Poisson distribution with parameter $\mu_{i t}$ which, in turn, depends 
on a set of exogenous variables $x_{i t}$ according to a log-linear function:

$$
\ln \mu_{i t}=\alpha_{i}+\beta x_{i t}
$$

where $\alpha_{i}$ captures the individual effect.

The fixed effects Poisson regression model allows for unrestricted heterogeneity across individuals, but requires the mean of counts for each individual to be equal to its variance, i.e., $E\left(y_{i t}\right)=V\left(y_{i t}\right)=\mu_{i t}$. This is an undesired feature whenever there is an additional heterogeneity not accounted for by the model, when the data show evidence of overdispersion. Such problem might be dealt with by assuming that the variable $y_{i t}$ has a negative binomial distribution (Hall, Hausman, \& Griliches, 1984), which can be regarded as a generalisation of the Poisson distribution with an additional parameter allowing the variance to exceed the mean.

In the Hall, Hausman and Griliches's (1984) negative binomial model it is assumed that $y_{i t} / \gamma_{i t} \sim$ Poisson $\left(\gamma_{i t}\right)$ and $\gamma_{i t} / \theta_{i} \sim \operatorname{Gamma}\left(\lambda_{i t}, 1 / \theta_{i}\right)$, where $\theta_{i}$ is the dispersion parameter and $\ln \lambda_{i t}=\beta x_{i t}$. This leads to the following density function:

$$
f\left(y_{i t} / \lambda_{i t}, \theta_{i}\right)=\frac{\Gamma\left(\lambda_{i t}+y_{i t}\right)}{\Gamma\left(\lambda_{i t}\right) \Gamma\left(y_{i t}+1\right)}\left(\frac{1}{1+\theta_{i}}\right)^{\lambda_{i t}}\left(\frac{\theta_{i}}{1+\theta_{i}}\right)^{y_{i t}}
$$

where $\Gamma$ is the gamma function. Looking at the within-group effects only, this specification yields a negative binomial model for $i$-th individual with:

$$
\begin{aligned}
& E\left(y_{i t}\right)=\theta_{i} \lambda_{i t} \\
& V\left(y_{i t}\right)=\left(1+\theta_{i}\right) \theta_{i} \lambda_{i t}
\end{aligned}
$$

Under this model the ratio of the variance to the mean (dispersion) is constant within group and equal to $\left(1+\theta_{i}\right)$.

Recent macroeconomic modelling has underlined the importance of knowledge spillovers, and externalities suggest that the equilibrium path of productivity growth may differ according to the extent of the diffusion of knowledge. In general endogenous, growth is guided by disembodied knowledge spillovers and the possibility to re-use existing knowledge may produce increasing returns and long run welfare effects. These knowledge driven macroeconomic models bring the attention to the different effects on growth rates of the different types of knowledge flows and push the empirical research to enquire in depth the processes of knowledge accumulation and decay and the different channels along which ideas may be transferred.

In fact, recent works have shown the usefulness of patent citations for exploring knowledge flows across regions, countries and technologies ${ }^{3}$. In the patent documents citations are used by examiners and applicants to show the degree of novelty and inventive step of the claims of the patent. They are located in the patent text, usually by either the inventor's attorneys or by patent office examiners and, once published, provide a legal delimitation of the scope of the property rights. Therefore citations identify the antecedents upon which the invention stands and, for this reason, they are increasingly used in economic research to gauge the intensity and geographical extent of knowledge spillovers and to measure the economic value of innovations.

The use of patent citations as an index of knowledge flow has been validated by a survey of inventors (Jaffe \& Trajtenberg, 1999, for the USPTO) and corroborates substantial evidence on the type and nature of knowledge spillovers (Maurseth \& Verspagen, 2002). Moreover patent citations are correlated with the value of patents and, in particular, recent work has shown that patent citations increase the market value of firms (Hall, Lotti, \& Mairesse, 2006) and that the number of citations is correlated with the reported value of the inventors

\footnotetext{
${ }^{3}$ See Peri (2005) for a relevant empirical analysis of regional knowledge flows by patent citations.
} 
and with the payment of patent renewal fees (Haroff et al., 1999).

If patent citations are an important track of knowledge spillovers and if forward citations are an important indicator of the economic value of innovative activity, the timing of the flow of citations and, in particular the citation-lag distribution, becomes extremely relevant. This is because the citation-lag distribution indicates for how long new technical knowledge spills over (identifying therefore a process of knowledge diffusion and obsolescence) and the time is needed to observe a sufficient number of forward citations and, consequently, to evaluate the importance of the invention.

\section{Absorptive Capacity: Definition and Measurement Issues}

The traditional definition of absorptive capacity is in Cohen and Levinthal's seminal paper (1989): It is the ability to recognize the value of new information, assimilate it, and apply it to commercial ends. For this reason, the absorptive capacity depends crucially on prior related knowledge. The authors make the investment in R\&D the fundamental element in their model of development of the absorptive capacity. The particular characteristic of this issue is its cumulativeness, in the sense that a firm has to invest on a constant basis in it.

Beyond the investment in R\&D to develop own absorptive capacity, other researchers have enriched its definition to analyse an organization's absorptive capacity. According to Zahra and George (2002), it is a set of organizational routines and processes by which firms acquire, assimilate, transform and exploit knowledge to produce a dynamic organizational capability. In particular, the authors distinguish two notions of absorptive capacity: the potential and the realized one.

The former consists in the firms' ability to identify and assimilate externally generated knowledge. Zahra and George (2002) consider the number of years of experience of the R\&D department and the amount of R\&D investment as signals of firms' knowledge acquisition activity, while the number of cross-firm patent citations, the number of citations made in a firm's publication to research implemented in other firms, as signals of the assimilation activity.

The latter consists in the firm's ability to combine existing knowledge and the newly acquired knowledge. The number of new product ideas and the number of new research projects may be treated as possible signals of firm's transformation activity. The realized absorptive capacity is also the firm's ability to apply the new assimilated knowledge in profitable products and services. The number of patents and the length of product development cycle could be signals of the firm's exploitation activity.

To measure the absorptive capacity of a firm, there exist different ways in the econometric models. In the production function approach context, the authors assume that the elasticity of output (or value added) to national or foreign stock of spillovers depends on the chosen measure of absorptive capacity, which generally is represented by own $R \& D$ capital. The positive effect of the interaction between own R\&D capital and the spillover pool term indicates the firm's ability to absorb new ideas from outside, while its negative effect gives evidence of necessity to invest more in own R\&D. Indeed, in this last case, a firm with low innovation rate cannot use other firms' new ideas and the competitive effect leads to a negative effect of the spillover pool. In the knowledge production function approach context, the researchers use information about self citations to takes into account the magnitudes of the absorptive capacity. A self citation indicates that a firm did some research in the past and that it has now generated a new idea building upon previous research in the same or in a related technology field. As such, self citations are a clear indication of accumulation of knowledge internal to the firm. The higher the average number of self citations in a sector, the more firms innovating within such 
sector build upon internal knowledge in generating new ideas. If the absorptive capacity argument is correct, then such firms should also display a higher ability to understand and exploit external knowledge. A way to formalise this is to allow the elasticity of innovation (patents) to spillover pools to depend on the chosen measure of the absorptive capacity. In this case the aim is to assess whether the elasticity is indeed higher the more firms have been engaged into R\&D activities in the same or related technological areas. Also in this case, we consider the interaction term between self citations and the spillover pool in the econometric model.

\section{Empirical Evidence}

In Table 1, we summarize empirical findings of models considering different dimensions of knowledge spillovers: technological and geographic.

Table 1

Comparative Analysis Based on Technological or Geographic Proximity

\begin{tabular}{|c|c|c|c|c|}
\hline Study & Data & Model & Estimation & S.E. \\
\hline Jaffe (1986) & $\begin{array}{l}432 \text { firms from } \\
\text { NBER R\&D }\end{array}$ & $\begin{array}{l}\text { OLS First-Diff } \\
\text { 3SLS }\end{array}$ & \begin{tabular}{|l|} 
Spillover effect \\
0.628 (OLS) \\
0.179 (First-Diff) \\
0.509 (3SLS)
\end{tabular} & $\begin{array}{l}0.11 \\
0.06 \\
0.10\end{array}$ \\
\hline Orlando (2004) & \begin{tabular}{|l}
515 US firms \\
$1972-1995$
\end{tabular} & $\begin{array}{l}\text { Within, between } \\
\text { groups }\end{array}$ & $\begin{array}{l}\text { Within } \\
\mathrm{G}_{\mathrm{N}} \mathrm{T}_{\mathrm{N}}: 0.010 \\
\mathrm{G}_{\mathrm{N}} \mathrm{T}_{\mathrm{d}}: 0.005 \\
\mathrm{G}_{\mathrm{d}} \mathrm{T}_{\mathrm{N}}: 0.011 \\
\mathrm{G}_{\mathrm{d}} \mathrm{T}_{\mathrm{d}}: 0.000 \\
\text { Between } \\
\mathrm{G}_{\mathrm{N}} \mathrm{T}_{\mathrm{N}}: 0.032 \\
\mathrm{G}_{\mathrm{N}} \mathrm{T}_{\mathrm{d}}: 0.009 \\
\mathrm{G}_{\mathrm{d}} \mathrm{T}_{\mathrm{N}}: 0.030 \\
\mathrm{G}_{\mathrm{d}} \mathrm{T}_{\mathrm{d}}: 0.002 \\
\end{array}$ & $\begin{array}{l}0.004 \\
0.005 \\
0.001 \\
0.001 \\
0.007 \\
0.002 \\
0.003 \\
0.001\end{array}$ \\
\hline $\begin{array}{l}\text { Bottazzi and } \\
\text { Peri (2003) }\end{array}$ & $\begin{array}{l}86 \text { European regions } \\
\text { over 1977-1995 }\end{array}$ & OLS & $\begin{array}{l}\text { Spillover } \\
\text { 0-300km: } 0.025 \\
\text { 300-600km: }-0.007 \\
\text { 600-900km: }-0.004 \\
\text { 900-1,300km: }-0.007 \\
\text { 1,300-2,000km: }-0.018\end{array}$ & $\begin{array}{l}0.01 \\
0.01 \\
0.01 \\
0.01 \\
0.01\end{array}$ \\
\hline $\begin{array}{l}\text { Aiello and } \\
\text { Cardamone (2008) }\end{array}$ & $\begin{array}{l}1,203 \text { Italian } \\
\text { manufacturing firms } \\
\text { over the period } \\
1998-2003 \text { from } \\
\text { Capitalia dataset } \\
\end{array}$ & $\begin{array}{l}\text { Two steps: Probit } \\
\text { and 3SLS }\end{array}$ & $\begin{array}{l}\text { (1) Symmetrical technological similarity: } 0.27 \\
\text { (2) Asymmetrical technological similarity: } 0.13 \\
\text { (3) Geographical proximity: } 0.35 \\
\text { (4) Asymmetrical technological and } \\
\text { geographical proximity: } 0.34\end{array}$ & $\begin{array}{l}0.008 \\
0.006 \\
0.009 \\
0.009\end{array}$ \\
\hline $\begin{array}{l}\text { Aldieri and } \\
\text { Cincera (2009) }\end{array}$ & \begin{tabular}{|l|}
808 International \\
firms over 1988-1997
\end{tabular} & GMM-SYS & $\begin{array}{l}\text { Technological proximity: } 0.61 \\
\text { Geographic proximity: } 0.41\end{array}$ & $\begin{array}{l}0.032 \\
0.023\end{array}$ \\
\hline
\end{tabular}

In particular, Jaffe (1986) introduces an interesting procedure to estimate spillover effects. Indeed, he constructs a technological space for the firms, and computes the proximity measure among them by the uncentered correlation coefficient, described in the previous section. In particular, he considers the number of patents as dependent variable and implements different econometric models, OLS, First-Differences and 3 Stages-Least-Squares (3SLS). He finds a positive effect of spillover pool on the firm productivity.

Orlando (2004) examines whether the geographic and technological distance attenuate inter-firm spillovers from innovative activity. The author distinguishes four spillover stocks: both geographically and technologically near firms $\left(G_{N} T_{N}\right)$, geographically near and technologically distant firms $\left(G_{N} T_{d}\right)$, geographically distant and technologically near firms $\left(G_{d} T_{N}\right)$ and both geographically and technologically distant firms $\left(G_{d} T_{d}\right)$. 
Parameter estimates obtained in a production function framework indicate that spillovers are significant and important from geographically and technologically proximate R\&D stocks. Results from the general analysis suggest that the importance of geographic proximity is conditional on technical relation between spillover sending and receiving units. Spillover from R\&D outside a firm's own narrowly defined industry group is increasing in geographic proximity. However, R\&D spillovers from within a firm's own industry are insensitive to distance. Conversely, evidence that technological similarity accentuates spillover is insensitive to distance between spillover sending and receiving units.

In contrast, returns from the R\&D of technologically distant firms are sensitive to geographic proximity to the spillover receiver. The finding that R\&D spillovers are largest among firms in the same narrowly defined industry may support arguments in defence of increased concentration in particular industries. To the extent that dominant firms internalise a larger fraction of total returns to innovative activity they will invest in more of it. Among technologically similar firms, the partial spillover enhancing effect of geographic proximity is much less significant. A defence of mergers between firms in a particular geographic region therefore may not be justified by the internalisation of knowledge spillover argument.

Bottazzi and Peri (2003) estimate the effect of research externalities across geographic space, in generating innovation. They do so, using R\&D and patent data on 86 European regions over 1977-1995. They claim that new knowledge, when codified, is available to everybody and therefore is a public good which influences the potential for new ideas everywhere in the world. However, new ideas which are not perfectly codified are embodied in people. Thus, they estimate the elasticity of innovation to R\&D and they find it to be positive and significantly different from 0 only for $\mathrm{R} \& \mathrm{D}$ done within $300 \mathrm{~km}$ of distance from a region. Its magnitude, though, is quite small: Doubling R\&D in a region would increase by $2 \%-3 \%$ the patenting activity in another region within $300 \mathrm{~km}$ of distance. The small size and the short range of these effects is consistent with the idea that such spillovers are the result of diffusion of non-codified knowledge between people who have frequent interactions. There is reason to claim that in Europe people commute and interact quite frequently within regions, while much less so if a longer trip is required. Moreover, they commute and interact more within than across countries and therefore a small border effect on these spillovers is detected. The range of these spillovers could very well be that of frequent face-to-face interactions, while the rest of knowledge flows is codified format and is not sensitive to the distance.

Aiello and Cardamone (2008) consider and compare different measurement methods of external technology to understand whether the role of R\&D spillovers is sensitive to the method used to weight the flows of innovation across firms. They assume that the greater the similarity between two firms in terms of size and R\&D efforts, the more they will absorb each other's technology. To overcome the problem that the similarity index produces a symmetric weighting scheme, the authors consider an asymmetric transformation of the uncentered correlation (see 2.2 for a description of their procedure). Econometrically, they use two steps: in the first step, they run the selection model that leads the firms to invest, or not, in R\&D. In the second step, they estimate a translog production function with the 3SLS method. Data are from Capitalia and are relative to a balanced panel data of 1,203 manufacturing firms over the period 1998-2003. They find that the output elasticity with respect to R\&D spillovers is always positive and significant. The geographical proximity is relevant in determining the result that the regressions based only on the asymmetric index of technological similarity underestimate the impact of R\&D spillovers.

Aldieri and Cincera (2009) investigate the extent to which R\&D spillover effects are intensified by both 
geographic and technological proximities between spillover generating and receiving firms. In particular, for the technological proximity, the authors use the distances of firms into a technological space constructed on the basis of the distribution of firms' patents across technological fields. In order to identify the geographical distance between the firms, the authors use the Haversine formula. From the empirical results of the GMM-SYS estimated model, we get that both the geographic and technological based R\&D spillovers stocks have an important and positive impact on the productivity growth of firms.

In Table 2, we consider the models trying to quantify the magnitude of the absorptive capacity of the firms.

Table 2

Comparative Analysis on Absorptive Capacity

\begin{tabular}{|c|c|c|c|c|}
\hline Study & Data & Model & Estimation & S.E. \\
\hline $\begin{array}{l}\text { Griffith, Redding and } \\
\text { Van Reenen (2003) }\end{array}$ & $\begin{array}{l}\text { 1801 US firms over } \\
1974-1990\end{array}$ & Within groups & 1.00 & 0.34 \\
\hline Grunfeld (2002) & $\begin{array}{l}105 \text { firms in Norway } \\
1989-1996\end{array}$ & Fixed-effect model & \begin{tabular}{|l|} 
Domestic spillovers: -0.6513 \\
Foreign spillovers: 0.8554
\end{tabular} & $\begin{array}{l}0.22 \\
0.26 \\
\end{array}$ \\
\hline Mancusi (2008) & $\begin{array}{l}\text { Patent citations data on } \\
14 \text { OECD countries over } \\
1978-2003\end{array}$ & $\begin{array}{l}\text { Negative Binomial } \\
\text { model }\end{array}$ & \begin{tabular}{|l} 
Leaders \\
National spillovers: 0.05 \\
International spillovers: -0.13 \\
Followers \\
National spillovers: -0.16 \\
International spillovers: 0.29
\end{tabular} & $\begin{array}{l}0.14 \\
0.11 \\
\\
0.11 \\
0.05\end{array}$ \\
\hline $\begin{array}{l}\text { Aldieri and Cincera } \\
(2009)\end{array}$ & $\begin{array}{l}808 \text { International firms } \\
\text { over 1988-1997 }\end{array}$ & GMM-SYS & $\begin{array}{l}\text { Technological proximity interaction: } 0.14 \\
\text { Geographic proximity interaction: } 0.11\end{array}$ & $\begin{array}{l}0.013 \\
0.013\end{array}$ \\
\hline
\end{tabular}

Griffith, Redding and Van Reenen (2003) start from a structural model of endogenous growth following Aghion, Howitt (1992), then they provide microeconomic foundations for the reduced-form equations for total factor productivity growth frequently estimated empirically using industry-level data. They think that R\&D efforts affect both innovation and the assimilation of others' discoveries (absorptive capacity). Indeed, the theoretical model identifies three key sources of productivity growth: R\&D-induced innovation, technology transfer, R\&D-based absorptive capacity. While microeconometric literature on $R \& D$ and productivity concentrates on the first, the empirical literature on productivity convergence focuses on the second. The authors find that all three sets of considerations are statistically and economically important, and confirm a key empirical prediction of the theory that an interaction term between R\&D and distance from the technological frontier should have a positive effect on productivity growth.

In Grunfeld (2002) the absorptive capacity of an industry, measured in terms of its R\&D intensity, helps to take advantage of the R\&D content flowing to the industry through imports. Thus, the study gives support to the importance of learning ability in the search of international R\&D spillovers. This is not the case however for domestic R\&D spillovers. He argues that industries with a high R\&D intensity often operate close to the technological frontier and find only productive spillovers from firms or industries that are equally advanced or even closer to the technological frontier. If such firms or industries are located abroad, there is little to learn from domestic sources.

Mancusi (2008) uses patent applications at the European Patent Office (EPO) and their citations from 1978 to 2003. The analyses explore applications at the EPO by firms located in 14 OECD countries. She implements an econometric model based on knowledge production function approach to pick up the absorptive capacity of the firms. In so doing, she considers the interaction between the self citations and the spillover pools 
terms, that is the national and the international stock of spillovers, computed taking into account the patent citations data. The empirical results show that absorptive capacity increases the elasticity of a laggard country's innovation to international spillovers (the so called "followers"), while its marginal effect is negligible for countries at the technological frontier (the so defined "leaders").

Aldieri and Cincera (2009) also control for the firm's ability to identify, assimilate and absorb the external knowledge stock. Including the firms' own R\&D stock, the spillover variables and the interaction between the two simultaneously in a Cobb-Douglas production function, the authors find a complementarity effect between own R\&D and both sources of R\&D spillovers.

Schmidt (2010) show that R\&D activities may not be useful to influence the firms' absorptive capacity. This depends on the type of knowledge the firms have to exploit. In particular, the author empirically explore the effect of R\&D activities, human resources and knowledge management, and the organization of knowledge sharing within a firm on the absorptive capacity of firms for three types of knowledge: absorptive capacity of knowledge from a firm's own industry, knowledge from other industries and knowledge from research institutions. He finds that R\&D intensity does not significantly affect absorptive capacity for intra- and inter-industry knowledge.

\section{Conclusions}

This work has provided an assessment of the recent literature on the knowledge spillovers and the absorptive capacity of the firms.

We have described the main econometric techniques to construct knowledge spillover pool, and then we have showed their empirical evidence. To this end, we have considered two possible dimensions: technological or geographic. If the concept of a technological space is very attractive, its measure is not direct and the choice of a distance metric can affect the nature of results. There is also the question of heterogeneity in the technological space. Moreover, given the positioning of firms into the technological space, we cannot know to what extent two firms benefit from spillovers given the possible existence of asymmetrical information flows. The timing of spillover effects should also be considered. Because of lags in the diffusion of knowledge, spillover effects are probably not immediate.

The references to earlier patent documents and scientific papers contained in patent documents can be used to infer spillovers arising from the knowledge described in the cited patent to the knowledge in the citing patent ${ }^{4}$. But also the use of patents to measure the knowledge flows is sensible to drawbacks, as discussed in Caloghirou, Constantelan and Vonortas (2006). First, they only provide indirect measure of the flows of knowledge. Indeed, in patent citations case, for example, the cited patent may not have contributed to the innovation, with the citation only included to build the patent claim or it may have only been added by the patent examiner. Second, they cannot evaluate tacit and embodied knowledge. Finally, they fail to capture the complexity of knowledge flows, which can follow a range of alternative paths in response to the strategic activities of different firms. Then, we conclude that a further empirical analysis is needed to pick out the asymmetrical flows, their dynamic trend and a direct measure of their absorptive capacity.

\footnotetext{
${ }^{4}$ See Hall, Jaffe and Trajtenberg (2001) for an explanation in using the patent citations data.
} 


\section{References}

Adams, J. D., \& Jaffe, A. B. (1996). Bounding the effect of R\&D: An investigation using matched establishment-firm data. RAND Journal of Economics, 27, 700-721.

Aghion, P., \& Howitt, P. (1992). A model of growth through creative destruction. Econometrica, 60(2), 323-351.

Aiello, F., \& Cardamone, P. (2005). R\&D spillovers and productivity growth. Further evidence from Italian manufacturing microdata. Applied Economics Letters, 12, 625-631.

Aiello, F., \& Cardamone, P. (2008). R\&D spillovers and firms' performance in Italy: Evidence from a flexible production function. Empirical Economics, 34, 143-166.

Aiello, F., \& Pupo, V. (2004). Il tasso di rendimento degli investimenti in Ricerca e Sviluppo delle imprese innovatrici italiane. Rivista di Politica Economica, XCIV, V-VI, 81-117.

Aldieri, L., \& Cincera, M. (2009). Geographic and technological R\&D spillovers within the Triad: Micro evidence from US patents. The Journal of Technology Transfer, 34(2), 196-211.

Bernstein, J. I., \& Nadiri, M. I. (1989). Research and development and intra-industry spillovers: An empirical application of dynamic duality. Review of Economic Studies, 56(2), 249-267.

Bottazzi, L., \& Peri, G. (2003). Innovation and spillovers in regions: Evidence from European patent data. European Economic Review, 47, 687-710.

Caloghirou, Y., Constantelan, A., \& Vonortas, N. S. (2006). Knowledge flows in European industry. Routledge edition.

Cincera, M. (2005). Firms' productivity growth and R\&D spillovers: An analysis of alternative technological proximity measures. Economics of Innovation and New Technology, 14(8), 657-682.

Cincera, M., \& Van Pottelsbergh, de la P. B. (2001). International R\&D spillovers: A survey. Cahiers Economiques de Bruxelles, $169,3-32$.

Cohen, W. M., \& Levinthal, D. A. (1989). Innovation and learning. The Economic Journal, 99(3), 569-596.

Evenson, R. (1968). The contribution of agricultural research and extension to agricultural production (PhD Thesis, University of Chicago).

Gertler, M. S. (1995). Being there: Proximity, organization, and culture in the development and adoption of advanced manufacturing technologies. Economy Geography, 71(1), 1-26.

Griffith, R., Redding, S., \& Van Reenen, J. (2003). R\&D and absorptive capacity: Theory and empirical evidence. Scandinavian Journal of Economics, 105(1), 99-118.

Griliches, Z. (1979). Issues in assessing the contribution of R\&D to productivity growth. Bell Journal of Economics, 10, 92-116.

Griliches, Z. (1992). The search for R\&D spillovers. Scandinavian Journal of Economics, 94, 29-48.

Griliches, Z., \& Mairesse, J. (1983). Comparing productivity growth: An exploration of French and US industrial and firm data. European Economic Review, 21, 89-119.

Griliches, Z., \& Mairesse, J. (1984). Productivity and R\&D at the firm level. In Z. Griliches (Ed.), R\&D, patents, productivity, Chicago, University of Chicago.

Grunfeld, L. A. (2002). International R\&D spillovers and the effect of absorptive capacity: An empirical study. Norwegian Institute of International Affairs.

Hall, B. H., Griliches, Z. \& Hausman, J. A. (1984). Econometric models for count data and an application to the patents-R\&D relationship. Econometrica, 52(4), 909-938.

Hall, B. H., Jaffe, A. B., \& Trajtenberg, M. (2001). The NBER patent citations data file: Lessons, insights and methodological tools (NBER Working Paper No. 8498).

Hall, B. H., \& Mairesse, J. (1995). Exploring the relationship between R\&D and productivity in french manufacturing firms. Journal of Econometrics, 65, 263-269.

Hall, B. H., Lotti, F., \& Mairesse, J. (2006). Employment, innovation, and productivity: Evidence from Italian Microdata. Industrial and Corporate Change, 17(4), 813-839.

Harhoff, D., Narin, F., Schrer, F. M., \& Vopel, K. (1999). Citation frequency and the value of patented inventions. The Review of Economics and Statistics, 81(3), 511-515.

Inkmann, J., \& Pohlmeier, W. (1995). R\&D spillovers, technological distance, and innovative success. Mimeo, University of Kostanz.

Jaffe, A. B. (1986). Technological opportunity and spillovers of R\&D: Evidence from firms’ patents, profits and market value. American Economic Review, 76(5), 984-1001. 
Jaffe, A. B. (1988). R\&D intensity and productivity growth. Review of Economics and Statistics, 70, 431-437.

Jaffe, A. B., \& Trajtenberg, M. (1999). International knowledge flows: Evidence from patent citation. Economics of Innovation and New Technology, 8, 105-136.

Los, B., \& Verspagen, B. (2000). R\&D spillovers and productivity: Evidence from US manufacturing microdata. Empirical Economics, 25(1), 127-148.

Lucas, R. E. (1988). On the mechanics of economic development. Journal of Monetary Economics, 22(1), 3-42.

Macdonald, S. (1992). Formal collaboration and informal information flow. International Journal of Technology Management, 7(1/2/3), 49-60.

Mancusi, M. L. (2008). International spillovers and absorptive capacity: A cross-country cross-sector analysis based on patents and citations. Journal of International Economics, 76(2), 155-165.

Maurseth, P. B., \& Verspagen, B. (2002). Knowledge spillovers in Europe: A patent citations analysis. Scandinavian Journal of Economics, 104(4), 531-545.

Medda, G., \& Piga, C. (2004). R\&D e spillovers industriali: Un’analisi sulle imprese italiane (Crenos Working Paper N. 2004/2006).

Morishima, M. (1967). A few suggestions on the theory of elasticity. Keizai Hyoron, 16, 144-150.

Orlando, M. J. (2004). Measuring spillovers from industrial R\&D: On the importance of geographic and technological proximity. RAND Journal of Economics, 35(4), 777-786.

Pakes, A., \& Griliches, Z. (1984). Estimating distributed lags in short panels with an application to the specification of depreciation patterns and capital stock constructs. The Review of Economic Studies, 51(2), 243-262.

Peri, G. (2005). Determinants of knowledge flows and their effect on innovation. The Review of Economics and Statistics, 87(2), 308-322.

Schmidt, T. (2010). Absorptive capacity-One size fits all? A firm-level analysis of absorptive capacity for different kinds of knowledge. Managerial and Decision Economics, 31, 1-18.

Terleckij, N. (1974). Effects of R\&D on the productivity growth of industries: An explanatory study. Washington, D.C.: National Planning Association.

Vinding, A. L. (2006). Absorptive capacity and innovative performance: A human capital approach. Economics of Innovation and New Technology, 15(4/5), 507-517.

Von Hippel, E. (1994). Sticky information and the locus of problem solving: Implications for innovation. Management Science, 40(4), 429-439.

Wagner, L. U. (1968). Problems in estimating research and development investments and stock. In 1968 Proceedings of the Business and Economic Statistics Section. Washington, D.C.: ASA, 189-197.

Wakelin, K. (2001). Productivity growth and R\&D expenditure in UK manufacturing firms. Research Policy, 30, 1079-1090.

WANG, Y. (2007). Trade, human capital, and technology spillovers: An industry-level analysis. Review International Economics, 15(2), 269-283.

Zahra, S. A., \& George, G. (2002). Absorptive capacity: A review, reconceptualization, and extension. Academy of Management Review, 27(2), 185-203. 